\title{
NARASI MODERASI BERAGAMA DALAM NASKAH SERAT CARUB KANDHA
}

\section{RELIGIOUS MODERATION NARRATIVE IN THE SERAT CARUB KANDHA MANUSCRIPT}

\author{
Agus Iswanto $^{1}$, Nurhata $^{2}$, Asep Saefullah $^{3}$ \\ ${ }^{13}$ Badan Penelitian dan Pengembangan dan Pendidikan dan Pelatihan, \\ Kementerian Agama Republik Indonesia \\ ${ }^{2}$ Sekolah Tinggi Keguruan dan Ilmu pendidikan \\ Pangeran Dharma Kusuma Indramayu, Indonesia \\ agus.iswanto83@gmail.com
}

DOI: $10.31291 / j \mathrm{lk.v19i1.910}$

Diterima: 06 Maret 2021; Direvisi: 03 Juni 2021; Diterbitkan: 30 Juni 2021

\begin{abstract}
The narrative of tolerance between ethnic groups or between religions is experiencing serious friction. There is a text that comes from the Cirebon tradition, which implicitly narrates about religious moderation in the early eras of Islamic development and port cities, namely Serat Carub Kandha. This article discusses three issues related to religious moderation in Serat Carub Kandha, namely: first, the context behind the writing and copying of the Serat Carub Kandha manuscript; second, the narrative of religious moderation in the Serat Carub Kandha script; third, its relevance to today's religious life in Indonesia. The source used as the primary research material is the Serat Carub Kandha manuscript collection by Rafan Hasyim in Cirebon in Pegon's writings. Using a philological and hermeneutic approach, this article shows that the Serat Carub Kandha Manuscript is historical evidence and collective memory of the practice of religious moderation in Indonesia's past, especially in the north coast of West Java. The moderation narrative that emerges is about respect for other religions, being accommodative to local culture, and anti-violence.
\end{abstract}

Keywords: Cirebon, Babad manuscript, religious moderation, Serat Carub Kandha 


\begin{abstract}
ABSTRAK
Narasi toleransi antarsuku bangsa atau antaragama mengalami gesekan serius. Terdapat sebuah naskah yang berasal dari tradisi Cirebon, yang menarasikan secara implisit tentang moderasi beragama pada era-era awal perkembangan Islam dan kota-kota pelabuhan, yaitu Serat Carub Kandha. Artikel ini membahas tiga masalah terkait dengan moderasi beragama dalam Serat Carub Kandha, yakni: pertama, konteks yang melatari penulisan dan penyalinan naskah Serat Carub Kandha; kedua, narasi moderasi beragama dalam naskah Serat Carub Kandha; ketiga, relevansinya bagi kehidupan beragama saat ini di Indonesia. Sumber yang dijadikan bahan primer penelitian adalah naskah Serat Carub Kandha koleksi Rafan Hasyim di Cirebon dalam tulisan Pegon. Dengan pendekatan filologis dan hermenutik, artikel ini menunjukkan bahwa Naskah Serat Carub Kandha menjadi bukti historis dan memori kolektif tentang praktik moderasi beragama di masa lalu Indonesia, khususnya di kawasan pesisir utara Jawa Barat. Narasi moderasi yang mengemuka adalah tentang sikap menghargai agama lain, akomodatif terhadap kebudayaan lokal, dan anti kekerasan.
\end{abstract}

Kata kunci: Cirebon, manuskrip Babad, moderasi beragama, Serat Carub Kandha

\title{
PENDAHULUAN
}

Sejumlah historiografi tradisional yang dinarasikan dalam naskah-naskah (manuscripts) asal Cirebon, tidak sedikit yang menyinggung tentang moderasi beragama. Kesemuanya merujuk pada kurun waktu sekitar abad ke-15 M., pada babak-babak awal perkembangan kota-kota pelabuhan yang memberikan warna berbeda dari era sebelumnya. Narasi-narasi tentang hal itu dalam naskah-naskah babad erat kaitannya dengan perkembangan agama Islam oleh dewan sangha, atau yang dikenal dengan Wali Sanga.

Hampir seluruh wilayah pesisir Jawa menemukan momentum baru pada abad ke-15-16 M, yang bersamaan dengan runtuhnya Kerajaan Hindu-Buddha dan perkembangan kerajaan-kerajaan Islam, tidak terkecuali dengan Cirebon. Cirebon, yang didirikan oleh Pangeran Walangsungsang, merupakan salah satu pusat kekuasaan dan perkembangan Islam di tengah konstelasi semacam itu. Zaman ini dianggap sebagai era keemasan bagi 
Cirebon, terutama ketika di bawah kepemimpinan Sunan Gunung Jati, penerus tahta Pangeran Walangsungsang. Erwantoro ${ }^{1}$ menyebut sebagai era keemasan karena Cirebon telah berhasil memisahkan diri dari Pajajaran. Kekuasan Cirebon melebar luas hampir sebagian besar dari Jawa Barat dan Banten.

Islamisasi di tanah Cirebon cukup berhasil, disertai adanya pembangunan infrastruktur dan suprastruktur. Prosesnya kemudian meluas ke sejumlah wilayah Pajajaran, yang meliputi Kuningan, Majalengka, Indramayu, Subang, Cianjur, Bandung, Sumedang, Garut, Tasikmalaya, dan Ciamis. Sementara penyebaran Islam di wilayah Barat dimulai dari Banten, yang persebarannya di daerah Banten Lama, Serang, hingga hampir seluruh Banten, kemudian Bogor, dan Sukabumi. Islam diterima di sana karena proses penyebarannya berlangsung damai, di samping karena kepentingan sosial, ekonomi, dan politik juga bermain di dalamnya. $^{2}$

Tahun 1447-1448 M, dalam naskah Negarakrtabhumi, penduduk Cirebon berjumlah 346 orang, 162 laki-laki dan 164 perempuan. Sebagian besar berasal dari Sunda dan Jawa. Mereka yang berasal dari etnis Sunda berjumlah 197 orang, dari Jawa berjumlah 106 orang, Swarnabhumi atau Sumatera 16 orang, Ujung Mendini atau Semenanjung Malaysia 4 orang, India 2 orang, Parsi atau Persia 2 orang, Siam atau Thailand 3 orang, Arab 11 orang, dan Cina 6 orang. ${ }^{3}$ Dalam naskah Cariyos Pangeran Walangsungsang, ada dua agama dominan yang berkembang pada abad ke-15 M, yakni Islam dan Buddha. Orang-orang dari berbagai daerah dan dari mancanegara ditengarai berasal dari agama dan aliran keagamaan yang berbeda pula,

\footnotetext{
${ }^{1}$ Heru Erwantoro, “Sejarah Singkat Kerajaan Cirebon,” Patanjala 4, no. 1 (2012): 170-83.

${ }^{2}$ Z. Mumuh Muhsin, "Penyebaran Islam Di Jawa Barat," Saresehan Nasional "Sejarah Perjuangan Syaikhuna Badruzzaman (1898 - 1972) (Garut, 2010).

${ }^{3}$ Atja and Ayatrohaedi, Nagarakretabhumi: Karya Kelompok Kerja Di Bawah Tanggungjawab Pangeran Wangsakerta Panembahan Cirebon (Yogyakarta: Departemen Pendidikan dan Kebudayaan Direktorat Jendral Kebudayaan, Proyek Penelitian dan Pengkajian Kebudayaan Nusantara (Javanologi), 1984), 108.
} 
namun sependek ini belum ada catatan yang menyebutkan bahwa perbedaan agama itu sebagai penghalang bagi masyarakat Cirebon kala itu.

Kecenderungan naskah babad mengalami pergeseran perspektif ketika memasuki era kolonialisme bangsa-bangsa Eropa. Narasi toleransi antarsuku bangsa dan antaragama mengalami gesekan serius. Satu sama lain saling berbenturan karena berbagai hal, terutama karena persoalan politik dan ekonomi. Di antara naskah yang menceritakannya adalah Babad Darmayu, yaitu tentang perseteruan antara penduduk lokal yang dipimpin oleh Bagus Rangin berhadapan dengan orang-orang Tionghoa di Celeng Indramayu pada awal abad ke-19 M. Perseteruan tragis kembali terulang ketika memasuk awal abad ke-20 M; ketika orang-orang Tionghoa dipaksa oleh para santri untuk melepaskan kuncirnya, untuk dijadikan sebagai azimat. Problem utamanya bukan terletak pada agama melainkan ekonomi, yang di dalamnya para ulama, sesepuh desa, dan para haji mengambil peran penting. ${ }^{4}$

Terdapat sebuah naskah yang berasal dari tradisi Cirebon, yang menarasikan secara implisit tentang moderasi beragama pada era-era awal perkembangan Islam dan kota-kota pelabuhan, yaitu Serat Carub Kandha. Secara sekilas, naskah tersebut menjelaskan bahwa sejak masa awal perkembangannya, wilayah pesisir utara Jawa bagian barat yang kini dikenal dengan Cirebon, adalah wilayah yang ditempati oleh masyarakat yang toleran. Orang-orang dari berbagai daerah, dari berbagai latar belakang suku bangsa, oleh penguasa wilayah diperbolehkan bermukim dan beraktivitas di sana. Lembaga pendidikan agama di tempat Syekh Quro misalnya, sebagai bagian dari Cirebon, yang saat itu berada di bawah kekuasaan Kerajaan Pajajaran, dapat menyebarkan agama Islam tanpa mengalami hambatan berarti. Awal mula berdirinya pun mendapatkan restu dari Prabu Siliwangi, sebagai penguasa Pajajaran kala itu. ${ }^{5}$

\footnotetext{
${ }^{4}$ Nurhata, Sedjarah Kuntjit: Suntingan Teks Dan Terjemahan (Jakarta: Perpustakaan Nasional RI, 2019).

${ }^{5}$ Rafan S Hasyim et al., Serat Carub Kandha (Bandung: Dinas Budaya dan Pariwisata Provinsi Jawa Barat, 2013). 
Artikel ini mengajukan bahwa naskah Serat Carub Kandha dipandang dapat menjadi argumen historis moderasi beragama di Indonesia. Isi naskah yang terkait dengan moderasi beragama tersebut tercermin dari, misalnya, kehidupan sosial dan budaya yang berbeda-beda, tetapi saling menghormati dan bekerja sama. Naskah Serat Carub Kandha memang tidak sepopuler Babad Cirebon, meskipun sama-sama berlatar belakang Cirebon. Suntingan naskah Serat Carub Kandha dalam berbagai versinya yang tersedia ${ }^{6}$ masih harus disempurnakan, serta dijelaskan konteks dan relevansinya dengan "dunia kehidupan" (lebenswelt) saat ini. Naskah ini selain menyajikan sebuah babakan cerita tentang suatu masa tertentu, juga memberikan sebuah pelajaran dan kearifan dari masa lalu tentang moderasi beragama yang penting dikaji.

Kajian-kajian tentang moderasi beragama yang berbasis pada sumber tertulis lama atau naskah kuna di Indonesia masih belum banyak dilakukan. Kajian-kajian yang membahas moderasi beragama pada sumber tertulis masyarakat lebih banyak pada teks-teks keilmuan keislaman. ${ }^{7}$ Sejumlah kajian yang ada

${ }^{6}$ Bambang Irianto and Tarka Sutaraharja, Babad Cirebon Carub Kandha Naskah Tangkil (Cirebon: Rumah Budaya Nusantara Pesambangan Jati Cirebon, 2013); Muhamad Mukhtar Zaedin and Tarka Sutarahardja, Carub Kanda Carang Satus (Cirebon, 2015); T.D Sujana and S.J Hadisutjipto, Carub Kandha Carang Seket (Jakarta: Departemen Pendidikan dan Kebudayaan, Proyek Penerbitan Buku Sastra Indonesia dan Daerah, 1980); Hasyim et al., Serat Carub Kandha.

${ }^{7}$ Kiai Abul Fadhal, "NALAR MODERATISME ISLAM Dalam Kitab Sharah Al-Kawakib Al- Lama' Ah Karya Kiai Abul Fadhal Senori Tuban," in 2nd Annual Confrence for Muslim Scholars (Surabaya: UIN Sunan Ampel Surabaya, 2018), 207-12; Rina Rehayati and Irzum Farihah, "Transmisi Islam Moderat Oleh Raja Ali Haji Di Kesultanan Riau-Lingga Pada Abad Ke-19," Jurnal Ushuluddin 25, no. 2 (2017): 172, https://doi.org/10.24014/jush.v25i2. 3890; Agus Iswanto, "Antara Ketaatan Beragama Dan Toleransi Sosial: Membaca Pemikiran Guru Marzuki Muara Di Betawi Tentang Kafir (18771934) Between Obedience and Social Tolerance: Reading Guru Marzuki Thought of Muara of Betawi on Kafir (1877-1934)," Jurnal Masyarakat Dan Budaya 18, no. 1 (2016): 33-46, https://doi.org/10.14203/JMB.V18I1.330; Muhammad Tarobin, "Moderasi Islam Dalam Kitab 'hidāyatul 'Awām Pada Menyatakan Perintah Agama Islam' Karya Muḥammad 'alwī Ibn 'abdullāh Khațīb Endah Al-Kamfāri,” Penamas 29, no. 3 (2016): 373-88; Syofyan 
tentang moderasi beragama lebih banyak dilakukan terhadap karya-karya ulama atau tokoh-tokoh Islam, lebih banyak mengajukan karya-karya yang berupa ajaran atau pemikiran, seperti kajian terhadap pemikiran Kiai Saleh Darat. Sementara itu, kajian narasi-narasi atau pesan-pesan moderasi beragama yang tertuang dalam naskah-naskah babad atau naskah-naskah cerita kesastraan, seperti naskah Serat Carub Kandha, masih perlu diperkaya. Oleh karena itu, penelitian ini dapat mengisi kekosongan kajian tentang moderasi beragama yang tertuang di dalam naskah cerita atau babad.

Rumusan masalah dalam artikel ini antara lain; pertama, apa konteks yang melatari penulisan dan penyalinan naskah Serat Carub Kandha? Kedua, bagaimana narasi moderasi beragama dalam naskah Serat Carub Kandha? Ketiga, bagaimana relevansinya bagi kehidupan beragama saat ini di Indonesia?

Ada dua konsep teoretis yang digunakan dalam penelitian ini. Pertama, adalah moderasi beragama; dan kedua, pemahaman tentang narasi moderasi dalam sebuah teks. Masing-masing konsep ini perlu dijelaskan sebagai jalan (the way to think) untuk menafsirkan naskah Serat Carub Kandha. Pertama, moderasi beragama dipahami sikap beragama yang seimbang antara pengalaman agama sendiri (eksklusif), dan penghormatan kepada praktik agama orang lain yang berbeda keyakinan. ${ }^{8}$ Moderasi beragama merupakan kunci terciptanya toleransi dan kerukunan, baik di tingkat lokal, nasional, maupun global. Moderasi beragama bukan tidak memiliki prinsip karena sikap keagamaan yang berada di tengah, tetapi justru merupakan sikap tegas terhadap sesuatu yang berlebihan.

Hadi, "Moderasi Teologis Dan Sufistik Di Nusantara Dalam Naskah-Naskah Puisi Keagamaan Ulama Minangkabau," Penamas 28, no. 2 (2015): 361-74; Saiful Umam, “God's Mercy Is Not Limited to Arabic Speakers: Reading Intellectual Biography of Muhammad Salih Darat and His Pegon Islamic Texts," Studia Islamika 20, no. 2 (2013), https://doi.org/10.15408/sdi. v20i2.388.

${ }^{8}$ Tim Penyusun Kementerian Agama RI, Moderasi Beragama (Jakarta Pusat: Badan Litbang dan Diklat Kementerian Agama RI, 2019), 18. 
Moderasi beragama memiliki beberapa indikator, yakni komitmen kebangsaan, toleransi, anti kekerasan, dan akomodatif terhadap kebudayaan lokal. ${ }^{9}$ Indikator pertama, komitmen kebangsaan, memang lebih tepat jika diterapkan dalam konteks Indonesia kontemporer yang sudah mewujud sebagai bangsa. Namun, untuk indikator kedua hingga keempat, toleransi, anti kekerasan, dan akomodatif terhadap kebudayaan lokal, adalah praktik moderasi yang dapat ditelusuri dalam berbagai khazanah kebudayaan dan tradisi tulis Nusantara. Oleh karena itu, ketiga indikator selain komitmen kebangsaan tersebut menjadi tolok ukur menilai narasi moderasi beragama dalam teks naskah Serat Carub Kandha.

Kedua, narasi dalam teks. Narasi secara bahasa berarti 'pengisahan suatu cerita atau kejadian' (kata benda), atau 'cerita atau deskripsi suatu kejadian atau peristiwa (kisahan)'. Dengan demikian, narasi berarti pengisahan suatu cerita tertentu yang berurutan waktu dan logis. Konsep narasi muncul karena pada dasarnya manusia senang akan cerita. Narasi dapat ditemukan dalam setiap domain kebudayaan. Narasi telah menembus berbagai disiplin ilmu terlepas dari kenyataan bahwa 'narasi' sebagai unit epistemologis telah diabaikan oleh disiplin ilmu selain studi budaya dan humaniora. ${ }^{10}$

Khazanah studi sastra dan budaya banyak berkaitan dengan kajian narasi, dan biasanya memiliki berbagai macam pendekatan atau kerangka teori dalam memahami narasi, seperti strukturalisme, post strukturalisme, semiotika, dan resepsi. ${ }^{11}$ Dalam konteks penelitian ini, narasi dipahami sebagai suatu cerita yang dipahami oleh pembaca (peneliti). ${ }^{12}$ Namun demikian, selain sebagai sebuah pemahaman peneliti atas obyek, narasi dipahami

\footnotetext{
${ }^{9}$ Tim Penyusun Kementerian Agama RI, Moderasi Beragama.

${ }^{10}$ Tommy Christomy, Signs of the Wali: Narratives at the Sacred Sites in Pamijahan, West Java (Canberra: ANU E Press, 2008), 10.

${ }^{11}$ Christomy, Signs of the Wali: Narratives at the Sacred Sites in Pamijahan, West Java.

${ }^{12}$ Jonathan Culler, The Pursuit of Signs: Semiotics, Literature, Deconstruction, The Pursuit of Signs: Semiotics, Literature, Deconstruction (London and New York: Routledge, 2005), 192, https://doi.org/10.4324/ 9780203996157.
} 
di sini sebagai suatu respon pembaca (pengarang/penulis) terhadap situasi sosial yang mendorong ditulisnya sebuah teks. Jadi, narasi di sini dipahami sebagai suatu cerita peristiwa yang dipahami oleh penulis sehingga menuliskan sebuah karya, dan narasi yang dipahami oleh peneliti sebagai suatu aktivitas penafsiran teks.

Sumber data penelitian ini adalah naskah Serat Carub Kandha koleksi Rafan Hasyim di Cirebon. Naskah ditulis dengan aksara Pegon, bahasa Jawa, pada kertas Eropa. Penulisnya adalah Pangeran Tujijaya Sukma atau Pangeran Linggabuana. Adapun waktu penyalinannya yaitu pada hari Sabtu tanggal 27 Rabiul Awal 1260 Hijriyah (1839 Masehi). Oleh karena itu, sebagai suatu teori penelitian naskah, filologi digunakan sebagai landasan teori. Pendekatan filologi ${ }^{13}$ tujuannya adalah untuk menjembatani komunikasi antara teks yang terdapat dalam naskah dengan pembacanya. Dengan demikian, tugas filolog adalah menghadirkan teks yang siap baca, dan selanjutnya melanjutkan interpretasi atas teks tersebut agar dapat dimengerti oleh pembaca.

Filologi juga dapat digunakan sebagai pendekatan, atau sebagai "alat bantu" yang dipinjam untuk menelusuri otentisitas teks. ${ }^{14}$ Hal itu dikatakan juga oleh Chambert-Loir ${ }^{15}$, yakni "filologi bukan sebuah tujuan, hanya sebuah peralatan." Kutipan di atas menunjukkan bahwa filologi adalah salah satu pemahaman saja dari beberapa pemahaman tentang filologi. Namun, pandangannya penting sebagai sebuah kerangka di dalam penelitian ini.

Pendekatan filologi berguna untuk menentukan judul sebuah teks dan pengarangnya atau masyarakat pengarang yang

${ }^{13}$ S.O. Robson, Prinsip-Prinsip Filologi Di Indonesia (Jakarta: Pusat Pembinaan dan Pengembangan Bahasa dan Universitas Leiden, 1994), 12.

${ }^{14}$ Oman Fathurahman, "Filologi Dan Kajian Islam Indonesia," in Filologi Dan Islam Indonesia, ed. Muchlis (Jakarta: Puslitbang Lektur Keagamaan, 2010), 10.

${ }^{15}$ Henri Chambert-Loir, Hikayat Nakhoda Asik Sapirin Bin Usman. Hikayat Merpati Mas Muhammad Bakir (Depok dan Jakarta: Masup Jakarta, Ecole française d'Extrême-Orient, dan Perpustakaan Nasional Republik Indonesia, 2009), 271. 
melahirkan teks. Pengkaji naskah yang tidak terlampau menghiraukan ikhwal filologis dari sebuah teks dalam naskah, karena memang tujuannya hanya mengkaji isi dan konteksnya, atau bahkan langsung mengkaji teks yang sudah "siap saji" (dari sebuah naskah atau beberapa naskah yang ada) sebagai sumber rujukannya karena yang dipandang penting adalah teksnya, maka ini akan berbenturan dengan klaim orisinalitas sebuah penelitian. ${ }^{16}$ Jika sumber penelitiannya adalah teks, dan teks itu berasal dari sebuah atau beberapa naskah, maka ia akan menelusuri terlebih dahulu seluk-beluk teks tersebut. Inilah maksud dari "filologi sebagai sebuah peralatan" sebagaimana kutipan di atas, yang juga diterapkan dalam penelitian naskah Serat Carub Kandha.

Pendekatan filologi tidak berhenti pada penelusuran otentisitas sebuah naskah, tetapi juga menafsirkan kandungan teks dalam naskah. Hal ini sebetulnya melanjutkan tugas filologi sebagaimana yang sudah disebut di atas, ${ }^{17}$ yakni tugas lanjutan yang masih melekat dalam diri seorang filolog adalah melakukan interpretasi atas teks yang dikaji. Setelah menelaah seluk-beluk dan otentisitas sebuah teks di dalam naskah, langkah selanjutnya adalah menafsirkannya. Penafsiran yang dikaitkan dengan relevansi teks dapat menggunakan prinsip-prinsip hermeneutika, terutama hermeneutika Gadamer. ${ }^{18}$ Model hermeneutik yang dapat digunakan dalam penelitian ini adalah sebagaimana yang diajukan oleh Gadamer. ${ }^{19}$ Hermeneutika bagi Gadamer adalah "memahami makna," bukan mengkritisi teks sebagaimana hermeneutika kritis Habermas. ${ }^{20}$

Menurut pandangan hermeneutika Gadamer, memahami dan menginterpretasi adalah proses yang melibatkan tegangan berbagai horizon, atau merupakan sebuah peleburan horizon

${ }^{16}$ Fuad Jabali, "Manuskrip Dan Orisinalitas Penelitian," Jurnal Lektur Keagamaan 8, no. 1 (2009): 3.

${ }^{17}$ Robson, Prinsip-Prinsip Filologi Di Indonesia.

${ }^{18}$ F. Budi Hardiman, Seni Memahami: Hermeneutik Dari Schleier macher Sampai Derrida (Yogyakarta: Penerbit Kanisius, 2015), 12.

${ }^{19}$ Hardiman, Seni Memahami: Hermeneutik Dari Schleiermacher Sampai Derrida.

${ }^{20}$ Hardiman. 
masa lalu dan masa kini. Interpretasi adalah sebuah perjumpaan seorang pembaca dengan teks. Hal tersebut berarti bahwa interpretasi adalah suatu perjumpaan kekinian pembaca dan tradisi yang melingkupi teks tersebut. Perjumpaan seperti itu menghasilkan tegangan antara horizon pembaca (peneliti) dan horizon teks. Menurut Gadamer, memahami bukanlah menghapus atau menghilangkan tegangan itu, yakni misalnya dengan membiarkan horizon teks menguasai horizon pembaca, tetapi justru mengeksplisitkan tegangan tersebut. ${ }^{21}$ Horizon masa kini yang dimaksud di sini adalah horizon moderasi beragama yang dieksplisitkan melalui tafsir atas Serat Carub Kandha.

\section{HASIL DAN PEMBAHASAN \\ Naskah Serat Carub Kandha}

Keberadaan naskah berjudul Carub Kandha dapat dilacak melalui katalog tentang naskah Cirebon. Sebagian telah dibuatkan katalognya dalam bentuk cetak (offline) dan daring (online). Temuan sementara, ada empat naskah: dua naskah terdaftar dalam katalog daring Portal Naskah Nusantara, ${ }^{22}$ yaitu koleksi Raden Achmad Opan Safari dan Elang Sulaiman; satu naskah terdaftar dalam Katalog Naskah Keagamaan Cirebon $2 ;^{23}$ satu naskah koleksi Bambang Irianto.

Pertama, naskah berjudul Wawaosan Carub Kandha, koleksi Elang Sulaiman, kode Crb/ES/04/2012. Penulis naskah bernama Pangeran Kartadiningrat, anak kedua dari Sultan Anom Muhammad Qomaruddin. Pangeran Kartadiningrat sebagai

${ }^{21}$ Agus Iswanto, "Epilog: Memproyeksikan Konsep Dan Nilai Pendidikan Berdasarkan Warisan Lokal Tertulis: Sebuah Upaya Membangun 'Jembatan' Melalui Fusi Horison Masa Lalu Dan Masa Kini,' in Nilai-NIlai Pendidikan Dalam Manuskrip Jawa, ed. Samidi (Yogyakarta: Arti Bumi Intaran, 2018), 237; Hardiman, Seni Memahami: Hermeneutik Dari Schleiermacher Sampai Derrida.

22،"Portal Naskah Nusantara," accessed April 11, 2020, http:// nusantara.dl.uni-leipzig.de/content/index.xml;jsessionid=5E2CCAD5ED22D0 CF86E17A2BDF6AA011?XSL.lastPage.SESSION=/content/index.xml.

${ }^{23}$ Zulkarnain Yani et al., Katalog Naskah Keagamaan Cirebon 2 (Tangerang Selatan: Pustaka Alvabet, 2019). 
pemilik pertama. Sementara itu, Sultan Anom Muhammad Qomaruddin yang dimaksud, ditengarai Sultan Anom VI. Artinya, waktu penulisannya diperkirakan awal abad ke-19.

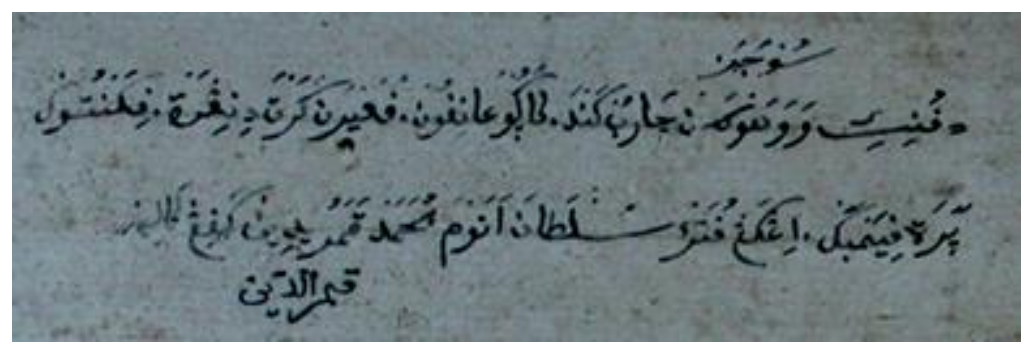

Sumber: Foto Naskah Serat Carub Kandha, 2020.

Gambar 1.

Kolofon Serat Carub Kandha

Naskah ditulis dengan aksara Pegon dalam bahasa Jawa, berbentuk tembang macapat, dengan tinta warna hitam. Kondisi naskah kusam dan sedikit kekuning-kuningan, tetapi teks masih jelas terbaca. Jumlah halaman naskah 186 dan terdiri atas 15 baris di setiap halaman. Ukuran naskah 39 x $20.5 \mathrm{~cm}$ dan blok teks 33 x $15 \mathrm{~cm}$. Alas tulis menggunakan kertas Eropa dengan cap kertas (watermark) yang tidak begitu jelas bertuliskan Concordia. Sebanyak 28 halaman terakhir tanpa teks. Pada lembar terakhir memuat teks beraksara Carakan (Jawa), di antaranya, menjelaskan Gua Gunung Djati yang bernama Sigalagala.

Isi teks mengisahkan perkembangan awal Negara Cirebon, ketika berada di bawah kekuasaan Kerajaan Pajajaran, pada masa Prabu Siliwangi. Awal teks menguraikan anak keturunan Nabi Muhammad Saw. sampai ke Jumadil Kubro. Jumadil Kubro memiliki seorang anak perempuan bernama Dewi Hami Araras. Dewi Hami memiliki putra bernama Syamsu Tamrin (Tamres). Imam Jumadil Kubra dikenal sangat kejam jika berperang melawan pasukan kafir.

Kedua, naskah berjudul Carub Kandha, koleksi Raden Achmad Opan Safari, kode Crb/OS/08/2012. Penulisnya Pangeran Tujijayakusuma atau Pangeran Linggabuwana: "Sejarah puniki dipun serat dumateng Eyang Yuyut Pangeran Tujijaya- 
sukma (Pangeran Linggabuana)." Naskah ditulis pada Sabtu, 27 Rabiulawal 1260 Hijriyah atau Selasa 16 April 1844.

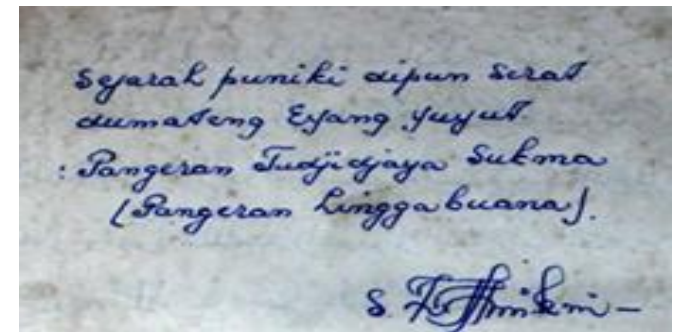

Sumber: Foto naskah Serat Carub Kandha, 2020.

\section{Gambar 2.}

Keterangan pemilik naskah dalam naskah Serat Carub Kandha

Naskah Carub Kandha ditulis dalam bentuk tembang macapat dengan aksara pegon, bahasa Jawa, dan ditulis dengan tinta hitam. Alas tulis menggunakan kertas polos dengan penomoran menggunakan angka Arab. Fisik naskah secara keseluruhan masih tampak baik dan sebagian besar teks jelas terbaca, hanya halaman terakhir saja yang sukar dibaca karena mengalami pelapukan. Teks tidak lengkap, halaman awal dan akhir hilang, dengan ketebalan keseluruhan 51 halaman. Setiap halaman terdiri atas 18 baris. Ukuran naskah 29 x $20.5 \mathrm{~cm}$; ukuran blok teks $26 \times 17 \mathrm{~cm}$. Naskah sudah dipreservasi, dijilid dengan kertas karton berlapis warna biru.

Adapun isi naskah Carub Kandha yaitu tentang perkembangan awal Cirebon, ketika masih menjadi desa kecil yang dipimpin oleh Ki Gedeng Alangalang. Masa itu bertepatan dengan Prabu Siliwangi. Pangeran Walangsungsang yang menjadi perintis kerajaan Cirebon. Teks diawali dengan anak keturunan Nabi Muhammad sampai Dewi Hami. Dewi Hami memiliki seorang anak bernama Syamsu Tamres, hasil perkawinannya dengan Nahkoda Haji Abdul Qodir.

Ketiga, naskah berjudul Sedjarah Tjirebon, kode 23/Sej/ BLAJ-MBI/2016, koleksi Mama Bambang Irianto. Judul naskah tertulis pada halaman depan: Sedjarah Tjirebon Jilid I. Penulis naskah H. Mahmmud Rais, diterjemahkan oleh Tarmono. Terdapat nama penyalin di halaman awal yakni M. Sudarjo, Mertapada kulon, Sindang laut, Tjirebon, tahun penyalinan 15 Desember 
1957. Selain itu juga ada keterangan: Kalau membaca sejarah ini jangan sembrono dan harus puasa dulu selama 7 hari. Catatan tambahan dalam naskah ini yaitu tentang sifat wajib Allah, rukun Islam, macam-macam sahadat, cara hitungan sehari-hari baik, perhitungan riwayat keluarga, macam-macam iblis dan perilakunya, dan macam-macam penyakit hati.

Kondisi alas tulis lapuk kusam, berwarna kekuning-kuningan. Sampul naskah kusam, naskah berlubang, penjilidan dijahit dengan benang dan hampir rusak. Halaman tanpa teks sebanyak 61 halaman, penomoran halaman di sebelah kiri, dan teks masih jelas terbaca dengan tinta berwarna hitam dan biru. Di dalam naskah berisi sembilan jilid ( $j l d I X$ ), kemungkinan yang dimaksud adalah bab, karena pada judul tertulis Sedjarah Tjirebon Jilid $I$.

Alas tulis menggunakan kertas bergaris, naskah ditulis dengan aksara latin dengan bahasa Indonesia. Teks ditulis dalam bentuk prosa dengan tebal 497 halaman. Setiap halaman terdiri dari 30 baris teks dengan ukuran naskah 21 x $16,5 \mathrm{~cm}$, dan ukuran blok teks 18 x $14 \mathrm{~cm}$.

Naskah Sedjarah Tjirebon berisi asal-usul Cirebon atau yang dikenal dengan babad Cirebon. Awal cerita, ada seorang ulama yang tinggal di Desa Karawang. Asalnya dari negara Cempa. Ia adalah putra Syekh Mouhammad Yusuf Sidiq, yang mana nasabnya terhubung ke Syekh Zainal Abidin hingga ke Nabi Muhammad Saw. Salah seorang santrinya bernama Nyi Subang Keranjang. Nyi Subang Keranjang adalah putri Sultan Melaka Singapura. Berita keberadaan santri perempuan itu terdengar oleh Prabu Siliwangi di Pajajaran. Akhir cerita mengisahkan Syekh Abdul Qodir Jailani, menjelaskan kepada muridnya bahwa malam pertengahan bulan Sya'ban adalah malam raja bagi para malaikat sebagaimana halnya malam Lailatul Kodar adalah malam raja bagi para malaikat.

Keempat, naskah berjudul Carub Kandha saja, koleksi Mama Bambang Irianto, kode BBD_CRB.08. Naskah ini sudah 
disunting oleh Bambang Irianto dan Tarka Sutaraharja. ${ }^{24}$ Penyunting memberi judul penelitiannya Babad Cirebon Carub Kandha Naskah Tangkil. Pemberian itu karena di dalamnya berisi cerita asal-usul Cirebon, dalam naskah tertulis judul "Carub Kandha", dan asal ditemukannya di Desa Tangkil (Cirebon). Penulis naskah bernama Ki Kampah, dari Sindang Laut: "Kula haji jalma ngaran Kampah Desa Karang Sembung Kulon, Dhistrik Sindang Laut Cirebon. Rumasa ges ngajual imah jeng pakarangan."

Kondisi naskah masih lengkap dan ditulis pada kertas bergaris. Naskah dijilid dengan kertas karton tebal dengan ketebalan naskah 231 halaman. Setiap halaman terdiri dari 17 sampai dengan 24 baris. Dimensi naskah $21 \times 16.5 \mathrm{~cm}$ dengan ukuran blok teks $18 \times 11 \mathrm{~cm}$. Teks ditulis dengan aksara Jawa, menggunakan tinta hitam.

Isi naskah tentang asal-usul Cirebon. Di dalamnya dikisahkan tentang tokoh Pangeran Cakrabuwana, Nyi Indang Geulis, Nyi Subang Keranjang, Nyi Syarifah Mudaim, Syekh Syarif Hidayatullah, Sunan Kalijaga, Nyi Mas Panguragan, dan para wali. Awal kisah, seperti naskah di atas, tentang Syekh Jumadil Kubra (Kabir), kelahiran Syamsut Tamres, dan seterusnya.

\section{Penyalin Naskah}

Abad ke-19 dan abad ke-20, banyak sekali ditemukan naskah yang memiliki kolofon, yang memuat keterangan nama penulis atau penyalin, waktu penulisan, dan tempat penulisan. Sebelumnya jarang dijumpai, terutama karena fisik naskah yang tidak lagi utuh, bagian awal dan akhir naskah, yang biasanya memuat informasi tentang itu. Pun kolofon pada suatu naskah tidak semuanya memuat penjelasan yang lengkap, seringkali hanya seperlunya saja yang barangkali menurut sang penulis naskah dianggapnya penting.

Dari dua naskah, yang dijadikan sebagai dasar kajian penelitian ini adalah koleksi Raden Achmad Opan Safari. Seperti

${ }^{24}$ Bambang Irianto and Tarka Sutaraharja, Babad Cirebon Carub Kandha Naskah Tangkil (Cirebon: Rumah Budaya Nusantara Pesambangan Jati Cirebon, 2013). 
telah dikemukakan di atas, naskah ini ditulis oleh Pangeran Tujijaya Sukma, pada tahun 1260 Hijriyah atau 1844 Masehi. Naskah ini ditulis oleh Pangeran Tujijaya Kusuma dinyatakan oleh Syarif Zaenal Asyikin, bukan oleh penulisnya (naskah) sendiri, tercatat pada halaman sebelum teks.

Indikasinya, pertama, gaya penulisannya berbeda dari teks utama. Kedua, warna tintanya juga berbeda dan ditulis pada lembar terpisah. Ketiga, terdapat tanda tangan Syarif Zaenal Asyikin. Keempat, terdapat keterangan cukup jelas di luar kolofon: "Sejarah puniki dipun serat dumateng Eyang Yuyut Pangeran Tujijaya Sukma (Pangeran Linggabuwana)".

Pada halaman awal dijelaskan, penyusunan Carub Kandha bersumber dari berbagai kitab. Ini memperlihatkan betapa penulis naskah memiliki perbendaharaan cerita yang cukup kaya, baik itu diperoleh dari proses membaca, menulis, maupun mendengar. Hanya saja nama kitab-kitabnya (naskah) tidak disebutkan.

Jika dilihat dari segi fisik naskah, kuat dugaan, Pangeran Tujijaya Sukma adalah penulis pertama. Ia menulis pada tahun 1844 M. Hasil tulisannya kemudian disalin pada tanggal 21 bulan Rowa tahun $1359 \mathrm{H}$ atau 24 September tahun 1940 M, di Dusun Kedawung, Onderdistrik Cirebon Barat. Penyalinnya, menurut pemilik naskah, adalah Pangeran Rahardiwijaya Jayakelana (tidak tertulis dalam naskah). Kemungkinan, pemilik naskah mengenalinya dari tanda tangan yang tertera di bawahnya.

Poenika sadjarah kaserat ping 21 Roewah 1359, oetawi 24 September 1940, ing doesoen Kedawoeng, Onderdistrik West Cheribon, kalawan tapak asta kaoela. Mugi-mugi Allah Soebhanahoe Wataala maringi rahmat wiloedjeng rahadjeng saha njoewoen paring berkah sjafaatipoen Gusti Djeng Nabi Moehammad Sollallohoe 'Alaihi Wasallam. Kalajan berkah karamatipoen para aulija miwah sagoeunging isining sadjarah poeniki. Amin. Amin. Amin.

Inilah sejarah yang ditulis pada tanggal 21 bulan Rowa tahun 1359 H, atau tanggal 24 September 1940, di Dusun Kedawung, Onderdistrik Cirebon Barat, beserta tanda tangan saya. Semoga Allah Subhanahu Wataala memberikan rahmat, selamat, dan rahayu. 
Semoga saya juga mendapatkan berkah dan syafaat dari Gusti Kanjeng Nabi Muhammad Sallallah 'Alaihi Wasallam. Juga, semoga saya mendapatkan berkah dan karomah dari para wali yang berkaitan dengan isi sejarah ini. Amin. Amin. Amin.

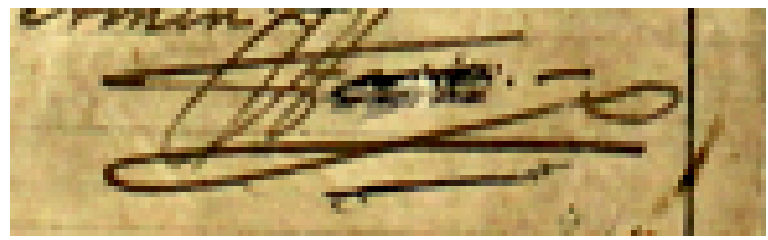

Sumber: Foto naskah Serat Carub Kandha, 2020.

Gambar 3.

Tanda tangan penyalin naskah

Kemungkinan lainnya, penyalin naskah ini adalah Eyang Yuyut Pangeran Tujijaya Sukma. Pangeran Tujijaya Sukma menyalinnya dari naskah yang ditulis pada tahun $1844 \mathrm{M}$. Nama penulisnya tidak disebutkan: anonim. Dengan kalimat lain, ada dua kemungkinan, Pangeran Tujijaya Sukma sebagai penulis (tahun 1844) atau penyalin (tahun 1940).

Pangeran Tujijaya Sukma, selain memiliki nama Pangeran Lingga Buwana, juga memiliki nama lain Pangeran Abdul Hamid Sukmajaya. Pangeran Tujijaya Sukma merupakan ayah dari Pangeran Rahadi Wijaya Jayakelana. Kakak kandung Pangeran Tujijaya Sukma bernama R. Siti Sukainah Padma Wisesa, ibu dari pemilik sekarang. Sementara itu, Syarif Zaenal Asyikin adalah cicit dari pemilik naskah saat ini.

Naskah Carub Kandha ditengarai berkembang dan popular di lingkungan keraton atau keluarga keraton. Dua naskah di atas, koleksi Elang Sulaiman dan Koleksi Raden Achmad Opan Safari, ditulis dan dimiliki oleh keluarga keraton. Ini tidak mengherankan karena naskah Carub Kandha termasuk kategori babad, yang bersifat istana sentris.

Selanjutnya, Pangeran Tujijaya Sukma memanjatkan doa semoga Allah Subhanahu Wata'ala memberikan rahmat, keselamatan, dan sehat sentosa. Penulis juga memohon berkah dan safa'at dari Gusti Kanjeng Nabi Muhammad Salallahu Alaihi Wasallam. Tidak lupa pula penulis memohon berkah dan karomah para wali, yang memang di dalam cerita naskah ini 
berkaitan dengan sejarah para wali: Mugi-mugi Allah Subhanahu Wata'ala maring rahmat wilujeng raharja saha nyuwun paring berkah safa'atipun Gusti Jeng Nabi Muhammad Salallahu 'Alaihi Wasallam, kalian berkah karomatipun para auliya miwah sagunging isining sajarah puniki Amin. Amin. Amin.

Pangeran Tujijaya Sukma memberikan penjelasan tentang keadaan yang dirasakan ketika menyusun naskah Carub Kandha. Berikut ini kutipannya:

Bismillahirohmanirohimi. Asmarané kang anulis kidung, sagung ing sejarah, ki bodo bingung akalé, angétonging timangsa, kawitaning wanci luhur, Saptu kaping pitulikur, ing sasi Robiul Awal, tahun Jim, Hijrah Jeng Nabi, séwu rongatus sewidak. Anerangi ing kiyengé, iku angati-atiya murwa kandhané wong kana. Malak mandal anak putu, antuk berkah safaat, permila remen anggurit, pawarta agunging sejarah. Lumayan kanggo pémuté kang sami sudi amaca, ing angsaling ceket khabar. Mila cinandak ing tutur, derapon énggal ngertos ora tilad perantining wawacan kang adawa. Kang pada gemet caturé, karna angring-kes carita, renteng ing kandha kang runtung, aja kedawon wicara lan yén kedawon angling, tanpa laba ingkang maca, akéh kang kéder tampané saking pusing pangindra, kédering tampiné kandha marmané mangka winangun kelawon babasan tarwa ora nganggo purwa kanthi, atilad lungiding sastra, tutur sawugjané baé kang kasebut ing sejarah, supaya pada runtuta ingkang kari anak putu, kang bodo derapon ngarti, ing sawising pada ngarti, ing sacaturing sejarah poma-poma aja gumaluwér, ing marta-bating auliya, bok bilih pada kuwalat, balik luruwen dén éstu malar-malar antuk berkah, karna iku kawitaning Nusa Jawa lampah Islam, iku singkono purwané aja tiba towung-towung, dupa suhudira den idep manah angaub, ing karomating auliya. ${ }^{25}$

\section{Terjemahan}

Bismillahirohmanir rochimi. Kebahagiaan orang yang menulis kidung, isi sejarah ini, bodoh dan bingung akalnya (dalam) menghitung titimangsa. Dimulai pada saat waktu dhuhur, hari Sabtu tanggal 27 Robiul Awal tahun Jim, Hijrah Nabi, 1260 (sekitar 16 April 1844). Memberi penerangan pada keinginan. Hati-hatilah terhadap ucapan orang dahulu (purwa kandha). Supaya anak cucu

${ }^{25}$ Halaman naskah 1. Lihat suntingan naskah dalam Hasyim et al., Serat Carub Kandha, 38. 
memperoleh berkah, syafa'at makanya senang membuat tulisan. Berita yang berisi sejarah lumayan untuk sekedar mengingat-ingat orang yang sudi membaca. Supaya dapat memperoleh berita. Agar ucapan itu dapat dimengerti. Tidak terkecuali yang lebih panjang yang habis isi ucapanbnya, karena memperpendek cerita. Urutan cerita tersusun, jangan terlalu banyak pembicaraan. kalau terlalu panjang tidak ada untungnya, tidak ada yang membaca, banyak yang salah terima. Karena membuat pusing ingatan. Sulit menerima cerita. Oleh karena itu dibuat dengan menggunakan bahasa biasa. Tidak memakai (kaidah) purwa kanthi. Mengingat ketajaman sastra. Bahasa biasa saja, yang disebutkan sejarah. Agar berurutan. Supaya anak cucu yang bodoh supaya mengerti. Setelah mengerti apa yang diceritakan sejarah. Awas jangan sekali-kali sok pintar. Kepada kedudukan para wali, supaya tidak kualat. Maka dari itu carilah dan benarkanlah agar memperoleh berkah, sebab itu merupakan asal usul pulau jawa mengenal islam. Dari situlah asalusulnya. Tidak datang secara mendadak. Oleh karena itu kesaksian kamu, disimpan dalam hati, terhadap karomahnya para wali.

\section{Latar Belakang Penulisan Naskah Serat Carub Kandha}

Penjelasan latar belakang penulisan Carub Kandha, dapat dilacak dan ditelaah dari naskah-naskah terkait yang memiliki usia lebih tua. Naskah Negarakrtabhumi, jika dilihat dari kolofon yang tertera dalam naskah Carita Purwaka Caruban Nagari, ${ }^{26}$ adalah naskah yang tertua. Naskah Carita Purwaka Caruban Nagari ditulis pada tahun 1720 oleh Pangran Arya Carbon. Artinya waktu penulisan naskah Negarakrtabhumi lebih tua dari itu. Namun demikian, naskah Negarakrtabhumi, yang diyakini sebagai salah satu karya Pangeran Wangsakerta, oleh para filolog, dianggap sebagai naskah "palsu", karena fisik naskah tampak masih baru dan kandungan isinya dianggap terlalu mengada-ada. ${ }^{27}$

Naskah Negarakrtabhumi, yang menjadi sumber penyusunan Carita Purwaka Caruban Nagari, kemudian keduanya

${ }^{26}$ Atja, Carita Purwaka Caruban Nagari (Bandung: Proyek Pengembangan Permuseuman Jawa Barat, 1986).

${ }^{27}$ Boechari, Melacak Sejarah Kuna Indonesia Lewat Prasasti (Jakarta: Gramedia, 2012); Nina H Lubis, "Kontroversi Tentang Naskah Wangsakerta," Humaniora 14, no. 1 (2012): 20-26, https://doi.org/10.22146/jh.v14i1.741. 
menjadi rujukan bagi naskah-naskah yang berisi cerita asal-usul Cirebon atau sejarah Cirebon. Hasilnya terdapat banyak kesamaan cerita, namun diberi judul berbeda-beda. Ini tidak mengherankan sebab tradisi penulisan atau penyalinan naskah-naskah lama sangat dinamis, sang penyalin memiliki kebebasan untuk menambahkan, mengurangi, atau mengubah plot, tokoh, atau latar cerita.

Beberapa naskah yang memiliki keterkaitan alur pembahasan dengan Negarakrtabhumi dan Carita Purwaka Caruban Nagari, antara lain berjudul Serat Carub Kandha, Babad Cirebon, Wawacan Sunan Gunung Jati, Sejarah Cirebon, dan Cariyos Pangeran Walangsungsang. Beberapa di antaranya, ada yang sebetulnya salinan, hanya diberi judul berbeda oleh penyalin, yang kemungkinan karena si peneliti baru bersentuhan dengan naskah semacam itu. Bagi mereka yang akrab dengan naskah Cirebon, ketika naskah yang dihadapinya berisi cerita asal-usul Cirebon, meskipun di dalamnya tanpa keterangan judul, mereka mafhum akan memberinya judul Babad Cirebon. Dengan kalimat lain, aneka macam judul juga terkadang disebabkan oleh penyalin.

Di samping karena peneliti, perbedaan judul juga karena memang unsur kesengajaan si penulis naskah, karena dalam proses penyalinannya ada banyak perubahan, sehingga oleh penulis naskah pantas diberi judul berbeda. Yang termasuk naskah semacam ini adalah naskah Cariyos Pangeran Walangsungsang $^{28}$, tertulis pada halaman depan, berisi cerita perjalanan Walangsungsang berguru kepada Syekh Nurjati dan penyebaran agama Islam oleh Sunan Gunung Jati.

Latar belakang penyusunan naskah Serat Carub Kandha, yang memiliki banyak keserupaan dengan dua naskah di atas (tahun 1720), ditengarai terkait dengan pembagian kekuasaan di keraton Cirebon. Hingga awal abad ke-19, Cirebon memiliki empat keraton, yaitu Kasepuhan (dahulu keraton Pakungwati), Kanoman, Kacirebonan, dan Kaprabonan.

${ }^{28}$ Titin Nurhayati Ma'mun, R. Achmad Opan Safari, and Nurhata, Cariyos Walangsungsang: Transliterasi Dan Terjemahan (Jakarta: Perpustakaan Nasional RI, 2018). 
Setiap keraton memerlukan legitimasi kekuasaan. Setiap sultan memerlukan nasab yang menghubungkan antara dirinya dengan leluhurnya, yaitu Sunan Gunung Jati, bahkan sampai ke Nabi Muhammad. Naskah Carub Kandha merunutnya lebih jauh lagi, sampai pada Sang Hyang Batara Nur Cahaya, yang menurunkan para dewa dan para tokoh dalam epos Mahabharata, hingga sampai pada raja-raja Jawa. Itu sebabnya, keberadaan naskah Carub Kandha tersebar menjadi koleksi keluarga keraton.

\section{Konteks Serat Carub Kandha}

Secara garis besar konteks cerita Carub Kandha yaitu tentang keadaan Cirebon dan wilayah pesisir utara Jawa Barat semasa di bawah kekuasaan Raja Pajajaran Prabu Siliwangi, sekitar abad ke-15. Masa ini bersamaan dengan melemahnya kerajaan-kerajaan di Nusantara serta kedatangan dan penyebaran agama Islam di wilayah pesisir di berbagai wilayah.

Banyak pendapat tentang teori kedatangan Islam di Nusantara. Satu di antara disampaikan oleh de Graaf dan Pigeaud (tt.). ${ }^{29}$ Menurutnya, Islam ditengarai masuk di tanah Jawa pada abad ke-13 melalui pintu Aceh, Sumatera Utara. Masa itu penguasa-penguasa di kota-kota pelabuhan di Aceh sudah banyak yang memeluk Islam. Mereka melintasinya dari jalur perdagangan laut yang terhubung dari pantai timur Sumatera ke laut Jawa melalui Indonesia bagian timur, yang mana sebetulnya sudah lama dilalui sebelum itu. Kemungkinan, banyak orang Islam di Jawa yang bermukim di wilayah-wilayah pesisir Jawa, termasuk nonmuslim, karena lingkungannya sangat mendukung.

Di Jawa Barat, Islam diperkenalkan oleh Bratalegawa putra Prabu Kuda Leleyan, Raja Galuh, pada tahun 1337. Bratalegawa dikenal dengan sebutan Haji Purwa atau Haji Barudin al-Jawi. Ia memeluk Islam ketika melakukan perjalanan perdagangan (saudagar) ke India. Atas bantuan orang Arab, Haji Purwa mencoba mengislamkan adiknya, tetapi gagal. Selanjutnya, Haji Purwa

${ }^{29} \mathrm{HJ}$ de Graaf and Th Pigeaud, Kerajaan-Kerajaan Islam Di Jawa: Peralihan Dari Majapahit Ke Mataram (Jakarta: Grafiti, n.d.). 
menetap di Caruban (Cirebon) Girang, wilayah kekuasaan Raja Galuh. $^{30}$

Penyebaran agama Islam di tanah Jawa, dalam banyak sumber, kerap kali dikaitkan dengan kehadiran para wali di tanah Jawa. Naskah Carub Kandha pada halaman awal, penulis naskah menuturkan:

Semoga orang-orang terdahulu yang menceritakan sejarah para wali Jawa atau para wali luar pulau Jawa, mendapatkan berkah. Menuliskan sejarah para wali yang luhur harus ikhlas supaya orang yang membacanya senang. Semoga orang yang membacanya mendapatkan manfaat dan taat kepada Yang Maha Agung. Selain itu, semoga cerita ini bermanfaat bagi sendi-sendi keislaman. Saya berpesan kepada pembaca supaya berhati-hati membacanya (agar tidak cepat rusak).

Di tanah Cirebon, seorang wali yang paling dikenal bernama Syekh Syarif Hidayatullah. Dari garis ibu, Syekh Syarif adalah anak dari Nyi Rarasantang, anak Prabu Siliwangi. Sementara dari garis ayah, ia adalah putra Raja Mesir. Syekh Syarif Hidayatullah atau Sunan Gunung Jati aktif menyebarkan agama Islam di tanah Jawa, dengan menggunakan media pengobatan atau kesaktian. Kisah ini banyak diuraikan dalam naskah babad yang jumlah salinannya melimpah.

\section{Narasi Moderasi Beragama}

Moderasi beragama dapat dimaknai sebagai sikap memilih jalan tengah dalam beragama atau berperilaku seimbang/adil dalam beragama. Salah satu aspek yang mesti dipertimbangkan adalah latar budaya setempat, sehingga suatu agama (Islam) tidak menjadi ancaman atau dianggap mengganggu stabilitas kultur yang ada. Masyarakat Cirebon, seperti digambarkan dalam naskah Serat Carub Kandha, memiliki pengalaman akan perihal itu yang masih relevan untuk diperkenalkan kembali kepada generasi milenial.

${ }^{30}$ Sobana Hardjasaputra and Haris Tawalinuddin, eds., Cirebon Dalam Lima Zaman (Abad 15 Hingga Pertengahan Abad 20) (Bandung: Dinas Pariwisata dan Kebudayaan Provinsi Jawa Barat, 2011), 45-46. 
Sebagaimana telah dikemukakan di atas, terdapat delapan poin penting tentang moderasi beragama yang termuat dalam naskah Serat Carub Kandha. Delapan poin tersebut dapat dikelompokkan menjadi tiga aspek. Tiga aspek ini seperti yang telah dijelaskan dalam kerangka teori tentang indikator moderasi beragama, yakni sikap menghargai agama atau keyakinan lain, akomodatif terhadap kebudayaan lokal, dan anti kekerasan. Berikut penjabarannya.

Pertama, sikap menghargai agama lain. Ini tercermin dari narasi berikut: Pupuh mijil, cabang kelima: ${ }^{31}$ Meskipun kerajaan Pajajaran beragama Buddha, namun penduduknya diperbolehkan memba-ngun pusat kegiatan belajar agama Islam, antara lain di tempat Syekh Quro, Karawang. ${ }^{32}$ Di pesantren itu, ada seorang putri cantik, bernama Subang Keranjang. Wajahnya terang sempurna, tak sedikit pun kekurangan. Asalnya dari Negara Singapura (Cirebon). ${ }^{33}$ Raja Pajajaran, Prabu Siliwangi menginginkan gadis itu untuk diperistri. Sang Guru, Syekh Quro, pada awalnya tidak merestui. Namun, pada akhirnya diizinkan untuk dijadikan sebagai istri. Di dalam istana kerajaan, Nyi Subang Keranjang selalu disanjung-sanjung, mendapatkan perlakuan baik dari pelayannya. Nyi Subang Keranjang memiliki tiga anak. Pertama, Pangeran Cakrabuwana, yang sangat tampan. Kedua, Nyi Rarasantang. Ketiga, Raja Sengara. Tiga anak itu kelak belajar agama Islam di Syekh Quro Karawang dan Syekh Nurjati Cirebon. Meskipun orang tuanya masih beragama Buddha.

\footnotetext{
${ }^{31}$ Halaman naskah 21-25 bait 33-130. Lihat suntingan naskah dalam Hasyim et al., Serat Carub Kandha, 89-90.

${ }^{32}$ Tempat belajar agama ini bisa disepadankan dengan istilah "pesantren" yang menurut beberapa sarjana baru muncul pada abad 18, dan mulai banyak digunakan pada abad 19. Lihat Martin van Bruinessen, "Pesantren and Kitab Kuning: Maintenance and Continuation," in Texts from the Islands: Oral and Written Traditions of Indonesia and the Malay World, ed. Wolfgang Marschall (Berne: The University of Berne Institute of Ethnology, 1994), 18.

${ }^{33}$ Sebuah daerah di Cirebon, bukan Singapura sebagaimana yang dikenal sebagi Negara Singapura sekarang.
} 
Pupuh Sumengker, cabang kesebelas: ${ }^{34}$ Orang-orang di pulau Jawa berbaur dengan orang Arab. Itu sudah menjadi kebiasaan. Air yang mereka gunakan sama. Orang Jawa turunan Asna, orang Arab turunan Nabi. Dari turunan Buddha banyak yang masuk ke Islam. Dari keturunan nabi ada yang menjadi kafir. Surga dan neraka sudah ada isinya: orang baik dan orang buruk. Itu keadilan Tuhan. Ada gelap ada terang. Ada pendek ada panjang. Ada yang derajatnya besar ada yang derajatnya kecil. Tuhan bisa saja menyamaratakannya. Tuhan bisa saja mengampuni semua hambanya. Namun, jika begitu manusia tidak ada yang ingat Tuhan. Semuanya diciptakan bermacammacam. Perbedaan itu sudah menjadi kehendak-Nya. Semuanya untuk beribadah.

Pupuh sinom, cabang ketiga belas: ${ }^{35}$ Pakuwon di Cirebon kala itu masih beragama Buddha. Kala itu banyak penduduk yang sakit. Supaya sembuh mereka harus masuk agama Islam. Cirebon kemudian berkembang luas. Pusatnya terletak di pesisir. Banyak orang berdatangan, dari negeri sebrang, negara Atasangin (Cempa), Bugis, Koja, Cina, Eropa. Beraneka suku bangsa bercampur baur. Sehingga wilayah pesisir itu sangat ramai. Orang-orang datang dan pergi sesuka hati. Siliwangi tidak me-larangnya. Orang-orang yang berdagang merasa nyaman. Mereka hanya diminta membayar pajak dalam jumlah yang kecil. Sri Bupati yang memungutnya. Dari situlah awal pembauran pendu-duk Cirebon. Penguasa Cirebon terus membenahi (infra-struktur) wilayah pesisir. Sang raja memimpinnya dengan bijak. Sang Raja Pajajaran yang berkuasa atas wilayah itu, melayani dan memberi izin. Tujuh orang dari anak dan saudara Sang Raja Pajajaran diperintah untuk menguasai (bertugas) dan melayani semua penduduk di sana. Beberapa daerah yang kala itu dipim-pin oleh anak dan saudara Prabu Siliwangi adalah Gemulung, Ender, dan Japura.

\footnotetext{
${ }^{34}$ Halaman naskah 41 bait 5-70. Lihat suntingan naskah dalam Hasyim et al., Serat Carub Kandha, 41.

${ }^{35}$ Halaman naskah $45-46$ bait 5-100. Lihat suntingan naskah dalam Hasyim et al., 154-55.
} 
Hal ini sesuai salah satu ciri moderasi beragama, yakni toleransi. Toleransi adalah sikap untuk memberi ruang dan tidak menggangu hak orang lain untuk berkeyakinan, mengekspresikan keyakinan, dan menyampaikan pendapat, meskipun berbeda. Oleh karena itu, toleransi adalah sikap terbuka, lapang dada, sukarela, dan lemah lembut dalam menerima perbedaan. Toleransi selalu disertai dengan sikap hormat, menerima orang yang berbeda sebagai bagian dari kita, dan berpikir positif. ${ }^{36}$ Sikap toleransi ini tentu relevan dan diperlukan untuk konteks sekarang. Sikap menghargai agama lain dalam negara Indonesia yang demokratis diperlukan sebagai landasan pelaksanaan pembangunan di segala aspek kehidupan yang lebih luas.

Kerajaan Pajajaran yang berorientasi agama Buddha, dalam narasi cerita Serat Carub Kandha di atas, menunjukkan toleransi terhadap penganut agama atau kepercayaan yang lain. Disebutkan bahwa meskipun raja memeluk agama Buddha, tetapi pemeluk-pemeluk agama lainnya dipersilakan menjalankan agamanya. Hal itu ditunjukkan dengan diperbolehkannya kalangan Muslim untuk membangun pusat belajar Islam, yakni di tempat Syekh Qura di Karawang. Sikap toleran juga ditunjukkan oleh beragamnya masyarakat Pajajaran, yang terdiri dari orang Arab dan Jawa, orang Buddha dan Islam. Selain itu disebutkan juga keseimbangan antara gelap dan terang, pendek dan panjang, besar dan kecil. Hal ini memberikan makna tentang moderasi yang berarti kesimbangan di antara dua sisi ekstrim.

Kedua, akomodatif terhadap kebudayaan lokal. Ini tercermin dari narasi berikut: Pupuh Ladrang, cabang kedelapan: ${ }^{37}$ Surya Salaka ingin berguru kepada Syekh Bairawa. Syekh Birawa menolaknya, "Tuan jangan berguru kepada saya. Hamba tidak pantas untuk menjadi guru tuan. Jika tuan ingin bertemu dengan istri tuan yang ada di barat dan di timur, tidak perlu repot mencarinya. Tunggu saja di Karang Kendal. Kelak jika tuan memiliki seorang anak perempuan, berilah nama Nyi Sembung Penatagama. Namun jika tuan memiliki anak laki-laki,

\footnotetext{
${ }^{36}$ Tim Penyusun Kementerian Agama RI, Moderasi Beragama.

${ }^{37}$ Halaman naskah $32-33$ bait $150-238$. Lihat suntingan naskah dalam Hasyim et al., Serat Carub Kandha, 115-19. 
berilah nama Sang Pangeran Karang Kendal, meskipun anakmu lahir di tanah Arab."

Pupuh Dhandanggula, cabang kedua belas: ${ }^{38}$ Agar selamat dari gangguan makhluk halus dan lancar dalam menjalankan roda pemerintahan, harus mengetahui para kebuyutan. Siapa pun yang berkusa, jika mengenal kebuyutannnya, maka akan dilindungi, dijaga kedudukannya oleh para buyut. Buyut-buyut itu adalah keturunan Prabu Siliwangi, yang silsilahnya sampai pada Ratu Galuh (berwujud siluman). Anak keturunan Galuh tetap dihormati, meskipun bukan beragama Islam. Mereka menjadi buyut yang mengayomi tanah Jawa, terutama Jawa Barat. Seni tradisi lokal menjadi bagian dari cara masyarakat menghormati leluhurnya (keturunan Galuh).

Sesuai dengan indikator moderasi beragama, orang-orang yang moderat lebih ramah dalam penerimaan tradisi dan budaya lokal dalam perilaku beragamanya, sejauh tidak bertentangan dengan ajaran pokok agama. Hal ini menunjukkan tradisi keberagamaan yang tidak kaku, yang ditandai dengan kesediaan untuk menerima praktik dan perilaku beragama yang tidak semata-mata menekankan pada kebenaran normatif. Dalam pupuh Ladrang, cabang kedelepan disebutkan sebuah anjuran untuk menggunakan nama yang tidak selalu berasal dari bahasa Arab, tetapi menggunakan bahasa sesuai asal-usul seseorang. Hal ini menunjukkan bahwa menjadi "Islam," tidak selalu menjadi "Arab," atau selalu menggunakan nama-nama Arab. Hal ini tiada lain adalah salah satu cara menghormati leluhur lokal yang menjadi pijakan asal-muasal tokoh. Hal ini juga tampak dalam pupuh Dhandanggula cabang kedua belas, yang menunjukkan penghormatan terhadap leluhur lokal mereka. Kenyataan sekarang ini, masyarakat Indonesia dalam beragama sering dilakukan dengan sarana kebudayaan di masing-masing wilayah. Hal yang penting ditekanankan adalah ajaran-ajaran pokok tidak tereliminasi di tengah sarana budaya lokal yang diajukan. Sebagaimana ditunjukkan dalam tiga pupuh di atas, ajaran pokok senantiasa dikedepankan meskipun dengan sarana budaya lokal, yakni meng-

${ }^{38}$ Halaman naskah 42 , bait 5-50. Lihat suntingan naskah dalam Hasyim et al., 143-45. 
ingat Tuhan (Allah), lebih mengedepankan substansi ajaran daripada simbol nama, dan penghormatan terahadap orang tua sebagaimana yang diajarkan oleh Islam itu sendiri.

Ketiga, anti kekerasan. Ini tercermin dari narasi berikut:

Pupuh Pangkur, cabang keempat: ${ }^{39}$ Nabi Muhammad menyabarkan agama Islam di seluruh dunia. Ajaran Islam terus menyebar hingga akhir zaman. Jika Islam berhenti menyebar maka kiamat segera tiba. Jadi, selama Islam masih ada, maka langit tidak akan runtuh. Namun demikian, manusia bisa mempercepat waktu menuju kiamat, hingga bumi menjadi hancur lebur. Di antara tanda-tandanya yaitu muncul banyak fitnah di antara manusia dan banyak orang yang menipu dan menyebarkan berita bohong atas nama agama. Orang semacam itu sejatinya merusak agama. Maka, tidak lama lagi, dunia akan hancur.

Pupuh di atas menarasikan bagaimana Islam disampaikan tidak dengan kekerasan, dan kekerasan-kekerasan yang terjadi cenderung berisifat politis untuk menguasai suatu wilayah. Pupuh Pangkur, cabang keempat menunjukkan bagaimana seharusnya Islam didakwahkan, yakni tidak dengan menebarkan fitnah, menebarkan berita bohong, dan menipu, apalagi dengan cara yang keras dan mengadu domba. Pupuh ini juga menegaskan bahwa Islam yang merupakan ajaran yang penuh dengan kedamaian akan tertutupi karena perbuatan-perbuatan orang yang merusak Islam meskipun dimaksudkan untuk menyebarkan Islam. Fitnah, berbohong, dan menipu adalah beberapa bentuk kekerasan verbal yang dhindari dalam moderasi beragama. ${ }^{40}$

Alih-alih menggunakan cara-cara kekerasan, Serat Carub Kandha menarasikan cara-cara damai dalam menyampaikan Islam, seperti juga yang tersebut dalam pupuh Mijil cabang keempat sebagaimana sudah dinarasikan di bagian pertama di atas. Pupuh tersebut menyebutkan bahwa Islam disebarkan melalui jalur pernikahan, sehingga dengan sendirinya Islam dapat diterima oleh masyarakat secara perlahan-lahan. Selain itu, pupuh ini juga menunjukkan bagaimana relasi yang harmonis

\footnotetext{
${ }^{39}$ Halaman naskah 18 bait 5-20. Lihat suntingan naskah dalam Hasyim et al., 75-76.

${ }^{40}$ Tim Penyusun Kementerian Agama RI, Moderasi Beragama.
} 
antara pemerintahan Kerajaan Pajajaran yang masih menganut Hindu-Buddha dengan masyarakat Islam yang sudah mulai banyak di wilayah tersebut. Hal ini tentu relevan dengan konteks kekinian, yakni dalam masyarakat yang beragam, hidup harmonis tanpa kekerasan diperlukan. Dakwah keagamaan dalam konteks negara demokratis sekarang ini tidak perlu dilakukan dengan cara-cara kekerasan yang justru akan melahirkan sikap antipasti masyarakat terhadap Islam, tetapi harus lebih mengedepankan perkataan dan perbuatan yang mencerminkan Islam yang damai.

\section{PENUTUP}

Naskah Serat Carub Kandha menjadi bukti historis dan memori kolektif tentang praktik moderasi beragama di masa lalu Indonesia. Bukti historis ini dibuktikan dengan pertimbangan filologis sebagaimana yang telah disampaikan dalam tulisan ini. Beberapa simpulan yang diajukan setelah pembahasan di atas adalah sebagai berikut.

Pertama, konteks cerita Carub Kandha adalah tentang keadaan Cirebon dan wilayah pesisir utara Jawa Barat semasa di bawah kekuasaan Raja Pajajaran Prabu Siliwangi, sekitar abad ke-15. Masa ini bersamaan dengan melemahnya kerajaankerajaan di Nusantara serta kedatangan dan penyebaran agama Islam di wilayah pesisir di berbagai wilayah. Latar belakang penyusunan Serat Carub Kandha (sekitar tahun 1720-an) ditengarai terkait dengan pembagian kekuasaan di keraton Cirebon. Hingga awal abad ke-19, Cirebon memiliki empat keraton, yaitu Kasepuhan (dahulu keraton Pakungwati), Kanoman, Kacirebonan, dan Kaprabonan. Setiap keraton memerlukan legitimasi kekuasaan. Setiap sultan memerlukan nasab yang menghubungkan antara dirinya dengan leluhurnya, yaitu Sunan Gunung Jati, bahkan sampai ke Nabi Muhammad Saw. Serat Carub Kandha merunutnya lebih jauh lagi, sampai pada Sang Hyang Batara Nur Cahaya, yang menurunkan para dewa dan para tokoh dalam epos Mahabharata, hingga sampai pada raja-raja Jawa. Itu sebabnya, keberadaan naskah Carub Kandha tersebar menjadi koleksi keluarga keraton. 
Kedua, narasi moderasi tersirat dalam delapan pupuh. Identifikasi ini dilakukan setelah melakukan pembacaan dan penyaduran. Pupuh-pupuh yang menarasikan moderasi beragama adalah: pupuh pangkur cabang keempat, pupuh mijil cabang keempat, pupuh megatruh cabang keempat, pupuh ladrang cabang kedelapan, pupuh perlambang cabang kesepuluh, pupuh sumengker cabang kesebelas, pupuh dandanggula cabang kedua belas, pupuh sinom cabang ketiga belas. Setiap pupuh tersebut menarasikan minimal satu nilai moderasi beragama yang dapat dikontekstualisikan dalam kehidupan masa kini.

Ketiga, terdapat delapan poin penting tentang moderasi beragama yang termuat dalam naskah Serat Carub Kandha. Delapan poin tersebut dapat dikelompokkan menjadi tiga aspek. Tiga aspek ini seperti yang telah dijelaskan dalam kerangka teori tentang indikator moderasi beragama yang relevan dengan konteks sekarang, yakni sikap menghargai agama lain, akomodatif terhadap kebudayaan lokal, dan anti kekerasan. Contohnya, sikap menghargai agama lain tercermin dalam pupuh mijil cabang keempat dan pupuh sumengker cabang kesebelas; akomodatif terhadap budaya lokal tercermin dalam pupuh megatruh cabang keempat, pupuh Ladrang cabang kedelapan, dan pupuh Dhandanggula, cabang kedua belas; anti kekerasan terdapat dalam pupuh pangkur cabang keempat.

Narasi moderasi beragama dalam naskah Serat Carub Kandha memerlukan suatu medium yang memungkinkan lebih banyak menjangkau kalangan serta lebih dikenal luas oleh generasi saat ini. Sedikitnya ada dua cara agar Serat Carub Kandha dikenal oleh masyarakat luas. Pertama, melalui pembelajaran di sekolah-sekolah, melalui mata pelajaran muatan lokal. Sasarannya adalah pelajar, yang semakin menajauh dari narasinarasi lokal akibat dari perkembangan globalisasi. Sumber yang digunakan dapat berupa buku ajar, buku cerita (komik), atau media visual (kanal youtube). Kedua, melalui media-media baru yang lebih dapat diakses secara luas dan menyenangkan oleh masyarakat, terutama generasi muda. Perlu membuat protype alihwahana dalam bentuk komik atau film animasi tentang moderasi beragama berdasarkan Serat Carub Kandha. 


\section{DAFTAR PUSTAKA}

\section{Buku}

Atja. Carita Purwaka Caruban Nagari. Bandung: Proyek Pengembangan Permuseuman Jawa Barat, 1986.

Atja, and Ayatrohaedi. Nagarakretabhumi: Karya Kelompok Kerja Di Bawah Tanggungjawab Pangeran Wangsakerta Panembahan Cirebon. Yogyakarta: Departemen Pendidikan dan Kebudayaan Direktorat Jendral Kebudayaan, Proyek Penelitian dan Pengkajian Kebudayaan Nusantara (Javanologi), 1984.

Boechari. Melacak Sejarah Kuna Indonesia Lewat Prasasti. Jakarta: Gramedia, 2012.

Bruinessen, Martin van. "Pesantren and Kitab Kuning: Maintenance and Continuation." In Texts from the Islands: Oral and Written Traditions of Indonesia and the Malay World, edited by Wolfgang Marschall, 121-46. Berne: The University of Berne Institute of Ethnology, 1994.

Chambert-Loir, Henri. Hikayat Nakhoda Asik Sapirin Bin Usman. Hikayat Merpati Mas Muhammad Bakir. Depok dan Jakarta: Masup Jakarta, Ecole française d'ExtrêmeOrient, dan Perpustakaan Nasional Republik Indonesia, 2009.

Christomy, Tommy. Signs of the Wali: Narratives at the Sacred Sites in Pamijahan, West Java. Canberra: ANU E Press, 2008.

Culler, Jonathan. The Pursuit of Signs: Semiotics, Literature, Deconstruction. The Pursuit of Signs: Semiotics, Literature, Deconstruction. London and New York: Routledge, 2005. https://doi.org/10.4324/9780203996157.

Fathurahman, Oman. "Filologi Dan Kajian Islam Indonesia." In Filologi Dan Islam Indonesia, edited by Muchlis. Jakarta: Puslitbang Lektur Keagamaan, 2010.

Graaf, HJ de, and Th Pigeaud. Kerajaan-Kerajaan Islam Di 
Jawa: Peralihan Dari Majapahit Ke Mataram. Jakarta: Grafiti, n.d.

Hardiman, F. Budi. Seni Memahami: Hermeneutik Dari Schleiermacher Sampai Derrida. Yogyakarta: Penerbit Kanisius, 2015.

Hardjasaputra, Sobana, and Haris Tawalinuddin, eds. Cirebon Dalam Lima Zaman (Abad 15 Hingga Pertengahan Abad 20). Bandung: Dinas Pariwisata dan Kebudayaan Provinsi Jawa Barat, 2011.

Hasyim, Rafan S, Nurhatta, Doddie Mulyanto, Aman Santosa, and Sri Wulandari. Serat Carub Kandha. Bandung: Dinas Budaya dan Pariwisata Provinsi Jawa Barat, 2013

Irianto, Bambang, and Tarka Sutaraharja. Babad Cirebon Carub Kandha Naskah Tangkil. Cirebon: Rumah Budaya Nusantara Pesambangan Jati Cirebon, 2013.

Iswanto, Agus. "Epilog: Memproyeksikan Konsep Dan Nilai Pendidikan Berdasarkan Warisan Lokal Tertulis: Sebuah Upaya Membangun 'Jembatan' Melalui Fusi Horison Masa Lalu Dan Masa Kini.” In Nilai-NIlai Pendidikan Dalam Manuskrip Jawa, edited by Samidi. Yogyakarta: Arti Bumi Intaran, 2018.

Ma'mun, Titin Nurhayati, R. Achmad Opan Safari, and Nurhata.

Cariyos Walangsungsang: Transliterasi Dan Terjemahan. Jakarta: Perpustakaan Nasional RI, 2018.

Muhsin, Z. Mumuh. "Penyebaran Islam Di Jawa Barat." Saresehan Nasional "Sejarah Perjuangan Syaikhuna Badruzzaman (1898 - 1972). Garut, 2010.

Nurhata. Sedjarah Kuntjit: Suntingan Teks Dan Terjemahan. Jakarta: Perpustakaan Nasional RI, 2019.

Robson, S.O. Prinsip-Prinsip Filologi Di Indonesia. Jakarta: Pusat Pembinaan dan Pengembangan Bahasa dan Universitas Leiden, 1994.

Sujana, T.D, and S.J Hadisutjipto. Carub Kandha Carang Seket. 
Jakarta: Departemen Pendidikan dan Kebudayaan, Proyek Penerbitan Buku Sastra Indonesia dan Daerah, 1980.

Tim Penyusun Kementerian Agama RI. Moderasi Beragama. Jakarta Pusat: Badan Litbang dan Diklat Kementerian Agama RI, 2019.

Yani, Zulkarnain, Saeful Bahri, Muhamad Rosadi, Mahmudah Nur, Nurhata, Tarka Sutaraharja, Abdullah Maulani, et al. Katalog Naskah Keagamaan Cirebon 2. Tangerang Selatan: Pustaka Alvabet, 2019.

Zaedin, Muhamad Mukhtar, and Tarka Sutarahardja. Carub Kanda Carang Satus. Cirebon, 2015.

\section{Jurnal Ilmiah}

Erwantoro, Heru. "Sejarah Singkat Kerajaan Cirebon." Patanjala 4, no. 1 (2012): 170-83.

Hadi, Syofyan. "Moderasi Teologis Dan Sufistik Di Nusantara Dalam Naskah-Naskah Puisi Keagamaan Ulama Minangkabau." Penamas 28, no. 2 (2015): 361-74.

Iswanto, Agus. "Antara Ketaatan Beragama Dan Toleransi Sosial: Membaca Pemikiran Guru Marzuki Muara Di Betawi Tentang Kafir (1877-1934) Between Obedience and Social Tolerance: Reading Guru Marzuki Thought of Muara of Betawi on Kafir (1877-1934)." Jurnal Masyarakat Dan Budaya 18, no. 1 (2016): 33-46. https://doi.org/10.14203/JMB.V18I1.330.

Jabali, Fuad. "Manuskrip Dan Orisinalitas Penelitian." Jurnal Lektur Keagamaan 8, no. 1 (2009): 1-30.

Lubis, Nina H. "Kontroversi Tentang Naskah Wangsakerta." Humaniora 14, no. 1 (2012): 20-26. https://doi.org/10.22146/jh.v14i1.741.

Rehayati, Rina, and Irzum Farihah. "Transmisi Islam Moderat Oleh Raja Ali Haji Di Kesultanan Riau-Lingga Pada Abad Ke-19." Jurnal Ushuluddin 25, no. 2 (2017): 172. https://doi.org/10.24014/jush.v25i2.3890. 
Tarobin, Muhammad. "Moderasi Islam Dalam Kitab 'hidāyatul 'Awām Pada Menyatakan Perintah Agama Islam' Karya Muḥammad 'alwī Ibn 'abdullāh Khațīb Endah Al-Kamfāri." Penamas 29, no. 3 (2016): 373-88.

Umam, Saiful. 'God's Mercy Is Not Limited to Arabic Speakers: Reading Intellectual Biography of Muhammad Salih Darat and His Pegon Islamic Texts." Studia Islamika 20, no. 2 (2013). https://doi.org/10.15408/sdi.v20i2.388.

\section{Website}

"Portal Naskah Nusantara." Accessed April 11, 2020. http://nusantara.dl.uni-

leipzig.de/content/index.xml;jsessionid=5E2CCAD5ED22D 0CF86E17A2BDF6AA011?XSL.lastPage.SESSION=/conte nt/index.xml

\section{Prosiding}

Fadhal, Kiai Abul. "NALAR MODERATISME ISLAM Dalam Kitab Sharah Al-Kawakib Al- Lama' Ah Karya Kiai Abul Fadhal Senori Tuban." In 2nd Annual Confrence for Muslim Scholars, 207-12. Surabaya: UIN Sunan Ampel Surabaya, 2018. 